\title{
The Investigation of the Rising Crime and the Reason for People to Indulge in the Crime in Bangladesh
}

\author{
Md. Kamrul Hasan1*, Munni Khatun² \\ ${ }^{1}$ School of Materials and Textile, Zhejiang Sci-Tech University, Hangzhou, China \\ ${ }^{2}$ Lalmatia Mohila College, Mohammadpur, Dhaka, Bangladesh \\ Email: ^kamrul041994@gmail.com
}

How to cite this paper: Hasan, M. K., \& Khatun, M. (2020). The Investigation of the Rising Crime and the Reason for People to Indulge in the Crime in Bangladesh. Advances in Applied Sociology, 10, 421-434. https://doi.org/10.4236/aasoci.2020.101002 $\underline{4}$

Received: September 20, 2020

Accepted: October 26, 2020

Published: October 29, 2020

Copyright $\odot 2020$ by author(s) and Scientific Research Publishing Inc. This work is licensed under the Creative Commons Attribution International License (CC BY 4.0).

http://creativecommons.org/licenses/by/4.0/

\begin{abstract}
In this paper, we focused on criminal activities, characteristics, reason, impact and preventive action of crime in Bangladesh. This study is an attempt to portray with special references of the comprehensive and holistic analysis of crime in Bangladesh. Recently in Bangladesh, social and political unsustainability is increasing day by day and is getting increasing different types of crime, drug business, violence, terrorism, kidnapping, murder, illegal business, overpopulation, politics, lack of education, and poverty. In Bangladesh, to reduce crime is the main motive, and various effective measures must be ensured, including public awareness, effective laws, and policies, police reform, and a proper justice system.
\end{abstract}

\section{Keywords}

Impoverishment, Drugs, Violence, Terrorism, Kidnapping, Murder, Illegal Business, Overpopulation, Politics, Lack of Education

\section{Introduction}

Bangladesh became independent on 16 December 1971 after almost 9 months of costly fighting. Now it is a developing country and still largely depends on agriculture but development grows fast. From the very beginning of the country's independence, Bangladesh has faced the problems of terrorism, violence, and corruption in its various manifestations (Khatun \& Islam, 2018). Crime has been a critical concern since the beginning of human society and Crime has been a critical concern since the beginning of human society, and human efforts to deal with this issue were only partially successful (Paranjape, 2007). 
Many researchers have offered several important explanations for the causes of the crime after a long period. The word "crime" comes from the Latin word "krinos" which means allegation. It includes actions that are against the social order and that deserve social criticism and condemnation. According to Black's Law Dictionary, "Crime is an act that the law makes punishable; the breach of a legal duty treated as the subject matter of a criminal proceeding". The Black Law Dictionary defines criminality as a positive or negative act in violation of criminal law and as an offense against the state (Garner, 2014). Edwin H. Sutherland has provided a definition of criminology that is widely accepted: Criminology is the body of knowledge of crime as a social phenomenon (Sutherland, 1934). According to Paul W. Tappan, "crime is a deliberate act or omission over criminal law committed without protection or excuse and punished by the Court as a felony or misdemeanor" (Kader \& Hussain, 2008). According to Blackstone, offenses are official corruption that constitutes a violation of duty on the part of the entire community (Nirmalak \& Zegye, 2012). Cross \& Jones define crime as a legal wrong, the remedy for which is the punishment of the offender at the instance of the State (More, 2020).

The word Crime has not been defined in the Bangladesh Penal Code. In its broad sense, however, it may be explained as an act of commission or omission which is harmful to society in general. But all acts tending to prejudice the community are not crimes unless they are punishable under the law. Bangladesh is lagging for various reasons. Crime, corruption, and the rule of law, lack of policy are the reasons for its backwardness. As in many developed countries, poverty has been an alarming social issue in Bangladesh for a considerable period of time. Shortly after independence, about $82 \%$ of the population lived below the poverty line (SAWAB, 2020). Bangladesh has made substantial strides in eliminating poverty. The tremendous progress achieved in alleviating poverty has been recognized by international organizations (Kim, 2016). Bangladesh is expected to reach the upper-middle-income class by 2041 at the current rise. Based on the current pace of poverty reduction, Bangladesh is expected to eradicate extreme poverty by 2021, nation to do so in South Asia (Chaudhury, 2018; Misha \& Sulaiman, 2016; Fan, 2016; Kopf, 2018). Thousands of people are moving from villages to urban areas due to unemployment and hunger. Yet towns are not able to support them adequately (Das, 2001).

Recently, the rate of crime is on the rise, and specific forms of offenses are steadily taking place. People are becoming victims of different forms of crime and children are now going to commit the crime. They experience violence from their culture and use drugs, and they even carry guns. The law enforcement officials face tougher challenges in regulating and overcoming tougher challenges in regulating. The number of police officers is lower in comparison to the population of this region. The police may not have decent preparation and lack adequate organizational assistance. Also, the political police criminal triumvirate is active in Bangladesh as a whole. Because of these factors, the police cannot play a 
significant part in the monitoring and prevention of crimes. Generally, crimes are divided into two categories: those relating to the human body and those related to property, and these two groups of crimes are prevalent in nearly all countries and cultures. In rural and urban areas, the nature of crime is distinct. Socio-economic and political fact is at the center of the gap. Crimes committed in rural areas include homicide, kidnapping, and docility, burglary, and stealing. The socio-economic environment of urban areas varies from that of rural areas; thus, the form of softer crime varies. As well as banks, shopping malls, and government offices are clustered in cities. People bring foreign cash, women wear prized ornaments, and a large sum of money is expended on commercial purposes. Both of these conditions provide immense possibilities for committing various kinds of offenses that are not possible in rural areas, with urban residents seeing two forms of reality, one during the day and the other at night. As soon as night falls, a cocaine dealer begins trafficking contraband drugs, prostitutes become involved to get their customers. Recently, crime is increasing in rural areas. The drugs and weapons business are increasing in these rural areas. Most of the illegal activities like, weapons business and drug businesses are supplying and selling in the night. In some areas, people do this illegal business from their own house. No one can stop their business, because everyone from the elder to children is taking drugs, and already addicted. Due to drug addiction and poverty, rural children are doing crime and in the night they are carrying weapons. In recent times children have been used to maintain some political people dominance in the countryside. The law cannot stop them. For that reason, also crime is increasing day by day. The society, the administration, and the government must be vigilant and also steps take drastic measures to prevent this crime. This paper focuses on the increase in crime, criminal activities, impact of increasing crime, preventive action against crime and fight against crime.

\section{Methodology}

Searches have been made to collect available literature through a personal search for criminal activities and preventive action, and also some specific criminal activities like drug supply, rape, kidnapping, murder, violence, terrorism, illegal business, etc. Information was also collected from texts, published journals, newspapers, websites, government records, and some personal observations.

\section{Discussion}

\section{1) The reason for the increase in Crime in Bangladesh}

Crime cannot increase without a reason. There are many serious reasons to increase crime in Bangladesh. Various cultures can also tend to classify crimes differently. In general, crime may clearly be described as a violation of the rules laid down by the governing authority of the country. The war against crime is not a new one in history. It has sought to bring down criminals since the foundation of civilization. Now let's try to look at some of the reasons for the of- 
fenses.

\section{a) Impoverishment and unemployment}

The impoverishment of Bangladesh peoples has been a troubling social. Shortly after independence, about $82 \%$ of the population stayed below the impoverishment line (SAWAB, 2020). Between 1972 and 2018, it is estimated that the population of Bangladesh live on less than $\$ 1.90 /$ day fell from $90 \%$ to $9 \%$. Between 2008 and 2018, the per capita income in the country rose by 149 percent (Ahmed, 2018). As of 2020, the inclusion rate for women in the workforce stands at 45 percent, while the net rate of female attendance in schools stands at a whopping 98 percent (Khatun, 2018; Islam, 2018). Bangladesh's national impoverishment rate in urban and rural areas declines very slowly. The rate of impoverishment reduction has increased in numerous cities and other cities remain unchanged. Many people live in remote areas where facilities such as education, health clinics, and adequate infrastructure, especially road links with markets, are missing. In rural areas, an estimated $35 \%$ of the population lives below the impoverishment line and approximately $21 \%$ of the population lives below the impoverishment line in urban areas (P.B., 2020). These Bangladeshis have poor access to health care and safe drinking water (Jahan, 2018). The rapidly increasing population increase is one of the major causes of rural impoverishment. It puts tremendous strain on the ecosystem, causing problems such as erosion and floods, which, in turn, contributes to poor agricultural productivity. The urban poor have occupations that require energy, thus impacting their health conditions. The urban people, however, are in a tough position to avoid impoverishment (Boyce, 2011).

Unemployment is a serious problem in Bangladesh. Many students completed his graduation but did not get a job. Some people are searching for a job for more than 10 years but still not getting a job. Mention age and experiences in government jobs. For this, people lost opportunities and remain unemployed. Table 1 below displays the unemployment rate, the youth unemployment rate, the annual adjustments, and also a comparison between the youth unemployment rate and the unemployment rate (Mactotrends, 2020).

In this table, the youth unemployment rate is more than the unemployment rate. Due to unemployment, most young people are involved in drugs and crime.

\section{b) Drug addiction}

Day by day drug addiction is increasing, from elder to child. All are addicted to many different types of drugs. Almost all types of drugs are available in Bangladesh and mostly drugs supplier are selling drugs from the evening. About 43 percent of the country's unemployed population is drug-addicted and in Bangladesh over 7.5 million people are drug-addicted. 80 percent of them are young people, 50 percent of whom are involved in multiple criminal activities. $48 \%$ of drug users are educated and 40 percent are uneducated out of the number. Sex criminals number about 57 percent, while human immunodeficiency virus is affected by 7 percent. 43 percent of women in the addicted population are taking yaba tablets. 
Table 1. Unemployment rate and comparison.

\begin{tabular}{cccccc}
\hline Years & $\begin{array}{c}\text { Unemployment } \\
\text { Rate (\%) }\end{array}$ & $\begin{array}{c}\text { Annual } \\
\text { Changes } \\
\text { Rate (\%) }\end{array}$ & $\begin{array}{c}\text { Youth } \\
\text { Unemployment } \\
\text { Rate (\%) }\end{array}$ & $\begin{array}{c}\text { Annual } \\
\text { Changes } \\
\text { Rate (\%) }\end{array}$ & $\begin{array}{c}\text { Differance between } \\
\text { Youth Unemployment } \\
\text { and Unemployment } \\
\text { Rate (\%) }\end{array}$ \\
\hline 2009 & 5.00 & -0.09 & 9.07 & 0.92 & 4.07 \\
2010 & 3.38 & -0.09 & 6.40 & -2.67 & 3.02 \\
2011 & 3.71 & 0.02 & 7.46 & 1.06 & 3.75 \\
2012 & 4.06 & -0.03 & 8.71 & 1.25 & 4.65 \\
2013 & 4.43 & -0.02 & 10.13 & 1.43 & 5.7 \\
2014 & 4.40 & -0.03 & 10.46 & 0.32 & 6.06 \\
2015 & 4.38 & 0.37 & 10.80 & 0.34 & 6.42 \\
2016 & 4.35 & 0.35 & 11.12 & 0.33 & 6.77 \\
2017 & 4.37 & 0.33 & 12.30 & 1.18 & 7.93 \\
2018 & 4.28 & -1.62 & 12.15 & -0.15 & 7.87 \\
2019 & 4.19 & 0.73 & 11.87 & -0.28 & 7.68 \\
\hline
\end{tabular}

Poor women and street children are involved in the sale and distribution of drugs of various kinds (Ahmed, 2019).

\section{c) Depression and mental Disorder}

Depression is an unhappy emotion. The main signs of depression are depressed mood and loss of interest and enjoyment (Sadock \& Sadock, 2003). When the male-female ratio is $1: 2$, it is shown that the frequency of depression ratio-wise is $3 \%-4 \%$ (Karim, Firoz \& Alam, 2001). In Bangladesh, the major depressive disorder has a lifetime prevalence of 4.6 percent (Firoz, Karim, \& Alam, 2007). The prevalence of depression is more common in females, due to unfavorable social circumstances. The frequency of major depression varies from $2.6 \%$ to $5.5 \%$ among males and from $6.0 \%$ to $11.8 \%$ among females (Dubovsky \& Dubovsky, 2002). A recent Canadian analysis using data from the National Public Health Survey has found that among young adults ( aged 12 to 25 years) the highest rates of the first occurrence of depression $(1.4 \%-9.1 \%$ of the public), and among those 65 years of age $(1.3 \%-1.8 \%)$ are lower (Patten, 2000; Mohit, Maruf, Ahmed \& Alam, 2011).

Mental illnesses are a significant global public health issue with greater pressures in low and middle-income countries. Mental disabilities are a significant public health concern and lead to 13 percent of the global disease burden calculated as years of life adjusted for disability (Mathers, Fat \& Boerma, 2015). Lowand middle-income nations have a greater psychiatric illness incidence relative to economically developed countries (Bass, Bornemann, Burkey, Chehil, Chen, Copeland, Eaton, Ganju, Hayward, Hock, Kidwai, Kolappa, Lee, Minas, Or, Raviola, Saraceno, \& Patel, 2012; Hock, Or, Kolappa, Burkey, Surkan, \& Eaton, 2012). Mental disorders have a significant negative impact on survival, and severe psychiatric disorders can decrease life expectancy by approximately 20 years 
when chronic diseases are present as a comorbid condition (Colton \& Manderscheid, 2006). Generally, mental illnesses are not viewed as a health issue (Hossain, Ahmed, Chowdhury, Niessen, \& Alam, 2014).

\section{d) State of the family}

Most crimes start from the family and later spread to the society. The initiation of all types of crime is family unrest and property. Since most families in the village are poor and illiterate, that's why there is no opportunity to consider what is right and what is wrong. An uneducated family cannot teach a proper lesson to their family child. In that cause, girls are getting married at an early age, children are involved in crime and children are taking drugs, being terrorists, carrying weapons, and beginning an illegal business.

\section{e) Inadequate education}

According to the study, kids should expect to get about 11 years of schooling in Bangladesh, but they miss around 4.5 of these because of the low standard of schooling. For instance, in Bangla, 35\% of grade 3 students scored too low to even be tested on reading comprehension, and just $25 \%$ of grade 5 students in the nation passed the minimum math threshold. The main reasons behind this are lack of access to early childhood learning services, inadequate quality educational methods, weak school administration problems, and insufficient total public education funding (Shi, 2019).

\section{f) An additional increase in population}

Table 2 is showing the growth of the population in Bangladesh and the rate of different ages people (WPP, 2019). Recently in Bangladesh, the population growth rate is 10 percent (The World Fact Book, 2018). From the beginning of the independence of Bangladesh are trying to control the population but still out of control because of uneducated people. Bangladesh's government is trying to reach its education system, family planning system, and free medicine for all.

\section{g) Abuse of political power}

Recently a common thing is the abuse of political power. Some people are very strongly involved with this. The government is sending relief for homeless and poor people, but they are not getting this relief. As soon as government relief arrives, they are sharing among themselves. Crime is being created today for all these influential people. Influential people are creating terror. Influential people are taking advantage of the weakness of the poor and uneducated people and

Table 2. Population in Bangladesh.

\begin{tabular}{cccccc}
\hline Year & $\begin{array}{c}\text { Total } \\
\text { population }\end{array}$ & $\begin{array}{c}\text { Yearly population } \\
\text { increase }\end{array}$ & $\begin{array}{c}\text { Population age } \\
(\mathbf{0}-14) \%\end{array}$ & $\begin{array}{c}\text { Population age } \\
(15-64) \%\end{array}$ & $\begin{array}{c}\text { Population age } \\
(64+) \%\end{array}$ \\
\hline 2000 & $>12.7$ crore & $>1$ crore & 37 & 59.2 & 3.9 \\
2005 & $>13.9$ crore & $>1.2$ crore & 34.4 & 61.3 & 4.3 \\
2010 & $>14.7$ crore & $>0.8$ crore & 32 & 63.2 & 4.8 \\
2015 & $>15.6$ crore & $>0.9$ crore & 29.3 & 65.6 & 5.1 \\
2020 & $>16.4$ crore & $>0.8$ crore & 26.8 & 68 & 5.2 \\
\hline
\end{tabular}


committing all kinds of misdeeds. Day by day young boys are joining them and help them in all their endeavors. They abuse political power and trade in drugs. These people are abusing this political power and helping to create all kinds of illegal activities. The government should keep a sharp eye on these people so that they are not in political parties and strict legal punishment needs to be provided for such people.

\section{2) Several of Bangladesh's criminal activities}

In recent time, the crime trend in Bangladesh has been increasing. Bangladesh should provide such severe punishment so that people are afraid to commit any crime for fear of this punishment. Some criminal activities are shown below.

\section{a) To create violence in society}

Political crime has become one of the major challenges currently facing the country. It affects the protection, well-being, and peaceful lifestyle of many people living in developed and developing countries alike. Yet the problem to date has been addressed primarily from an interventionist viewpoint, with military and security interventions aimed at counteracting violent extremism. Nearly half of the 1.5 billion people living in unstable and conflict-affected nations are young people and one can understand how these facts have generated a public image of youth as either victims or perpetrators of abuse. Yet, as the Youth Action Strategy for Stopping Conflict and Fostering Unity states, "this narrative fails to reflect the fact that most youths are part of the solution," and that most youths oppose conflict (Ahmed, 2017).

\section{b) Growing up drug business}

In terms of geographical location, Bangladesh is located at the critical point between the 'golden triangle' Myanmar, Thailand, and Laos and the 'golden crescent' Pakistan, Afghanistan, and Iran. It is also surrounded by Asia's main drug-producing nations, all of which are tightening their drug regulations and scaling up security efforts. Bangladesh is becoming a major transit point with its fast land, sea, and air links. Traffickers selling narcotics to the North American, African, and European markets route their shipments via Bangladesh's Dhaka, Chittagong, Comilla, Khulna, and other roads (Islam \& Hossain, 2017). It is suspected that more and more people are going to get interested in the drug industry with the growing quantity of wares. And this way, in the end, it also adds to the number of substance addicts.

\section{c) Growing up independently illegal arms business}

In recent time, weapons have become available to all types of people. Some people are earning money from this weapons business. They are selling various types of weapons at mid-night and they have some listed buyers. These types of people have their own economic, social, and political agendas. These people frequently possess illegal weapons and use them when they feel necessary. To meet their purposes, they often threaten the security of the state and individuals through the use of arms to conduct illegal and violent activities. Therefore, the use of illicit weapons has been growing among ordinary persons in society (Rana 
\& Nesa, 2018). Thus, in Bangladesh, three main non-state consumers of illicit weapons are political cadres, terrorists, and militants, among others, who also risk people's lives, the security of society, and, through their violent criminal activities, the life of the regime.

\section{d) Terrorism}

In the past, Bangladesh has witnessed terrorism guided by many local Islamist militant organizations (Terrorism in Bangladesh, 2020). The Bangladeshi government claims that both ISIL and had claimed to be involved in the country in the past, however, that they worked largely through local affiliates before being neutralized by security forces. In 1989, when a network of 30 separate groups was set up and extended in the following years, the first Bangladeshi Islamist militant factions formed. Most Islamist groups in Bangladesh have as their key aim to establish a separate Islamic state or rule Bangladesh under Sharia law. Terrorist attacks against both the government and the general public have been carried out by Islamist groups.

\section{e) Blackmailing and Rape}

The term blackmailing and rape is very similar in Bangladesh. The word rape originally comes from the Latin rapre (Saunders, 2001; Burgess-Jackson, 1999). Since the $14^{\text {th }}$ century, the term has been used to mean to snatch and carry away by force. In Roman law, the capture of a woman by force, with or without intercourse, constituted raptus (Burgess-Jackson, 1999). In medieval English law, the same term may be used to refer either to rape in the contemporary sense of sexual violation (Saunders, 2001). Child, teenager girls, adult girls, and women are the victim of rape and blackmailing. People are blackmailing by showing some antisocial pictures, videos, and defamatory work and also being raped day after day at one stage. This kind of activity is done by some people who are miss-using political power. The victims are suffering, and can't tell anyone because they know there is no one to help them.

\section{f) Kidnapping and Murder}

Kidnapping and murder is a common thing in Bangladesh. Such activities are usually carried out to retain political power, regional power, social power, and hereditary power. Some people are doing murder openly. They don't care whether it is day or night. They are doing these activities as if it is their right. Such activity is increasing in sufficient quantity day by day. People are afraid of them and from this side, people are living like helpless. The murder rate in Bangladesh in the past few years is shown in Table 3 below.

\section{g) Cyber Crime}

Cybercrime is growing day by day worldwide. Bangladesh's cybercrime conviction rate is 3\%. The tribunal data indicate that in 2018, the court received 925 cybercrime cases, and in the first two months of 2019, as many as 130 cases (DhakaTribune, 2019). Cybercrime is relentless, undiminished, and unlikely to stop, writes CSIS Senior Vice President James Lewis, author of the report. It's just too easy and too rewarding, and it is perceived that the chances of being 
Table 3. Murder rate in Bangladesh.

\begin{tabular}{ccc}
\hline Year & Rate (\%) & Changing Rate (\%) \\
\hline 2010 & 2.7 & -6.53 \\
2011 & 2.7 & -1.68 \\
2012 & 2.7 & 2.54 \\
2013 & 2.9 & 5.55 \\
2014 & 2.9 & 1.59 \\
2015 & 2.6 & -11.61 \\
2016 & 2.3 & -11.97 \\
2017 & 2.2 & -2.23 \\
2018 & 2.4 & 6.79 \\
\hline
\end{tabular}

caught and punished are too low. Some steps to avoid cybercrime: 1). Uniform implementation of fundamental security measures, such as regular updates and patches of software. 2). Increased cooperation from international law enforcement. 3). Cybersecurity laws more stringent in several countries. 4). Sanctions for countries that harbor cybercriminals. Cybercrime will continue to grow without these types of activities as the number of connected devices grows and as the value of online activities increases.

\section{h) Human Trafficking}

Bangladesh is a source and transit city for the trafficking of men, women, and children, especially forced labor and forced prostitution. We can see three forms of human trafficking, there's sex trafficking, child sex trafficking, labor trafficking.

Sex trafficking: When an adult is required to engage in a commercial sex act, as a result of force, threats of force, fraud, coercion, or any combination of such means, that person is a victim of trafficking. Bangladeshi women and children are also trafficked for commercial sexual abuse in India.

Child sex trafficking: In Bangladesh, both boys and girls are trafficked for commercial sexual exploitation, bonded labor, and forced labor. Some children are sold by their parents in bondage while others are induced by fraud and physical coercion into work or commercial sexual exploitation. Such a child under the age of 18 who has been abducted, enticed, imprisoned, transferred, given, marketed, preserved, supported, or required to engage in a commercial sex act is a victim of trafficking regardless of whether or not abuse, deception, or coercion is used.

Labor trafficking: Men recruited for jobs overseas with fake job opportunities who are eventually abused under conditions of forced labor or bondage are a large share of Bangladesh's trafficking victims. Trafficking of labor involves a variety of procurement, sheltering, shipping, supplying or receiving practices requiring the use of force or physical threat; sexual coercion; violation of legal process; a strategy, method, or pattern structured to keep an individual of fear of serious harm; or other manipulative means to compel people to function. 
Bangladeshi men and women willingly migrate for work to Saudi Arabia, Bahrain, Kuwait, the United Arab Emirates, Qatar, Iraq, Lebanon, Malaysia, Liberia, and other countries, often legally and contractually. Thereafter, women who work overseas are trafficked for commercial sexual slavery. Children and adults are also trafficked internally for commercial sexual exploitation, domestic servitude, and bonded labor.

3) Impact of increasing Crime in Bangladesh:

a) Social impacts of Violence: Crimes of violence in Bangladesh have diminished since independence. But there are still some violent crimes in Bangladesh and there are frequent violent criminal activities such as murder, aggravated assault, rape, kidnapping, riot, violent crime, child abuse, violence against women, theft, robbery, drug dealing, etc,. For these types of activity still, people are not independently living their life, women cannot go outside independently, children cannot go to school smiley and now people spend their day in fear.

b) The psychological impact: The psychological effect of crime is sometimes as significant or greater than the financial or physical effect. The Victim's Rights Campaign has successfully claimed that under-compensation provision should be expanded to include psychological treatment for crime-related psychological injuries as well as physical accidents or economic damages (Kilpatrick, Veronen, Saunders, Best, Mullan, \& Paduhovich, 1987).

c) The economic effect of illegal conduct: Criminality is profoundly affected by the economic circumstances of a region. Currently, the most significant reasons for crime in Bangladesh are economic factors such as violence, unemployment, injustice, etc. A part of the population in Bangladesh, as citizens of a developing country, lives below the poverty line. The criminals here are mostly from the poorer classes and their prime motivation for the crime is monetary gain. When the economic misery of the poor villagers knows no bounds, in villages crimes such as burglary, robbery, and dacoity increase. Although the population is being sifted, it is too little to deal with the situation and the maximum is living in the slum area. Here the miserable state of society, the scarcity of jobs produces an incapacity to uphold an acceptable quality of living and thereby causes criminality such as substance misuse, theft, hijacking, kidnapping, youth delinquency, etc. as a way of raising money.

d) Increase of political corruption and Instability: Political crime is an offense involving transparent actions or omissions that harm the rights of the society, the administration, or the political system. Political crime implies any criminal actions carried out against the people by federal or state authorities with political intent and any unlawful acts carried out against the State by the citizens. Treason, sedition, police brutality, confrontation, and crossfire are generally considered political crimes sponsored by the state. Also, terrorism, murder and criminal conspiracy are regarded as an anti-state political crime. Government or ruling class offenses are analogous to white-collar crimes since they are part of the aggression by ruling class citizens in society, such as bureaucrats, ca- 
pitalists, and high-profile academics, who are generally lawmakers or enforcers. It can be noted that this type of crime is occasionally reported in Bangladesh. However, Bangladesh's police statistics contain a separate form of the crime called political assassination, which is still underreported due to political interference.

\section{4) The preventive action against crime:}

Social steps to deter offenses: The government has to take steps to keep control of the population and make strict laws for it. All the people of the society must be compelled to obey this law. To ensure the optimal behavior and food of infancy of children, all institutions have to take appropriate steps to keep people away from crime. All religious institutions should need to give the right knowledge to keep people away from crime.

Economical steps to deter offenses: For all unemployed citizens, the government must arrange proper employment facilities and also must need steps to improve the standard of living.

Legal steps to deter offenses: Must be law enforcement agencies activism, have the system of the effective and speedy court, have to apply the proper rules and regulations, and also have to reform in the justice system.

\section{5) Social worker intervention in the fight against crime:}

- Need to increase consciousness among people.

- Have to help to formulate crime-related policies.

- Have to build a strong social movement.

- People in society need to give the right advice the criminals to avoid crime.

- Everyone in society needs to be given a proper opportunity of an education.

- The reasons for the crime must be identified and make the rule against it in society.

- Have to increase research on crime and appropriate steps to be taken.

With the changing in time, new criminals are arising and conventional criminals are gradually disappearing, but the issue continues in disturbing ways notwithstanding legal, socioeconomic, psychological, and punitive steps to curb crime.

\section{Conclusion}

Finally, it found that fiscal, social, and political factors are largely responsible for shifting the dynamics and trends of crime rather than regional, environmental, and criminal justice influences. In Bangladesh, social and political unsustainability is increasing day by day and is getting increasing different types of crime, drug business, violence, terrorism, kidnapping, murder, illegal business, overpopulation, politics, lack of education, and poverty. In Bangladesh, to reduce crime is the main motive and various effective measures must be ensured, including public awareness, effective laws, and policies, police reform, and a proper justice system. While there is a lack of reliable crime data and scientific studies on the origin of crime, it needs a great deal of focus. Researchers, academics, 
law enforcement officials have to further research to recognize problems and have numerous successful steps, including the development of effective legislation and regulations, the reform of the judiciary, the reform of the legal system. The reform of the justice system should be maintained to strengthen the situation and resolve the crime issue in Bangladesh. If the correct actions are not taken now, criminal activity will increase day by day.

\section{Conflicts of Interest}

The authors declare no conflicts of interest regarding the publication of this paper.

\section{References}

Ahmed, G. M. S. (2017).

https://www.peaceinsight.org/blog/2017/03/crime-violence-and-extremism-bangladesh -how-rebuild-society

Ahmed, K. A. (2018). Per Capita Income Increases by 149\% in 10 Years. Dhaka Tribune, 25 September 2018.

Ahmed, K. A. (2019).

https://www.dhakatribune.com/bangladesh/dhaka/2019/02/27/43-of-unemployed-pop ulation-addicted-to-drugs

Bass, J. K., Bornemann, T. H., Burkey, M., Chehil, S., Chen, L., Copeland, J. R. M., Eaton, W. W., Ganju, V., Hayward, E., Hock, R. S., Kidwai, R., Kolappa, K., Lee, P. T., Minas, H., Or, F., Raviola, G. J., Saraceno, B., \& Patel, V. (2012). A United Nations General Assembly Special Session for Mental, Neurological, and Substance Use Disorders: The Time Has Come. PLOS Medicine, 9, e1001159. https://doi.org/10.1371/journal.pmed.1001159

Boyce, J. K. (2011). Poverty Profile People's Republic of Bangladesh, Executive Summary.

Burgess-Jackson, K. (1999). A Most Detestable Crime: New Philosophical Essays on Rape (p. 16). New York: Oxford University Press.

Chaudhury, D. R. (2018). At Current Pace, Bangladesh to End Extreme Poverty by 2021. The Economic Times.

Colton, C. W., \& Manderscheid, R. W. (2006). Congruencies in Increased Mortality Rates, Years of Potential Life Lost, and Causes of Death among Public Mental Health Clients in Eight States. Preventing Chronic Disease, 3, A42.

Das, B. L. (2001). Oporadhabiggan. In Theoretical Criminology (Vol. 1, 2nd ed., p. 316). Dhaka: Kamrul Book House.

DhakaTribune (2019).

https://www.dhakatribune.com/cybersecurity/2019/04/20/3-conviction-rate-of-cybercr ime-in-bangladesh

Dubovsky, S. L., \& Dubovsky, A. N. (2002). Concise Guide to Mood Disorders. Washington DC: American Psychiatric Publishing Inc.

Fan, Q. M. (2016). Bangladesh Can Overcome Extreme Poverty through More Inclusive Growth.

Firoz, A. H. M., Karim, M. E., \& Alam, M. F. (2007). Community Based Multi-Centric Service Oriented Research on Mental Illness with Focus on Awareness, Prevalence, Care, Acceptance and Follow-Up in Bangladesh. Manual on Mental Health for Primary 
Health Care Physicians (2nd ed.). NIMH \& WHO.

Garner, B. A. (2014). Black's Law Dictionary.

Glory Nirmalak, K., \& Zegye, S. (2012). The Concept of Crime.

Hock, R. S., Or, F., Kolappa, K., Burkey, M. D., Surkan, P. J., \& Eaton, W. W. (2012). A New Resolution for Global Mental Health. The Lancet, 379, 1367-1368. https://doi.org/10.1016/S0140-6736(12)60243-8

Hossain, M. D., Ahmed, H. U., Chowdhury, W. A., Niessen, L. W., \& Alam, D. S. (2014). Mental Disorders in Bangladesh: A Systematic Review. BMC Psychiatry, 14, Article No. 216.

Islam, A., \& Hossain, M. F. (2017). Drug Abuse and Its Impact on Bangladesh. International Journal of Sociology and Anthropology, 9, 143-156. https://doi.org/10.5897/IJSA2016.0736

Islam, R. (2018). BBS Labor Force Survey 2016-17: Female Labor Force Growth Dwarfs Males. Dhaka Tribune, 20 March 2018.

Jahan, F. (2018). Bangladesh-Poverty and Wealth. Encyclopedia of the Nations.

Kader, M., \& Hussain, Md. M. (2008). Criminology (p. 21). Dhaka: Suchona Publishers.

Karim, M. E., Firoz, A. H. M., \& Alam, M. F. (2001). Assessment of Depression in Parkinson's Disease, Psoriasis, Stroke and Cancer Patients. Bangladesh Journal of Psychiatry, 15, 11-18.

Khatun and Islam (2018). Crime in Bangladesh: A Historical Overview. Social Science Review, 35, 1-33.

Khatun, F. (2018). Women's Participation in the Job Market. The Daily Star, 8 March 2018.

Kilpatrick, D. G., Veronen, L. J., Saunders, B. E., Best, C. L., Mullan, A. A. M., \& Paduhovich, J. (1987). The Psychological Impact of Ctime: A Study of Randomly Surveyed Crime Victims. Washington DC: National Institute of Justice.

Kim, J. Y. (2016). Learning from Bangladesh's Journey toward Ending Poverty. https://doi.org/10.1596/31096

Kopf, D. (2018). Bangladesh's Rapid Growth Is One of the World's Happiest Economic Stories. qz.com. Quartz.

Mactotrends (2020). https://www.macrotrends.net/countries/BGD/bangladesh/unemployment-rate

Mathers, C., Fat, D. M., \& Boerma, J. T. (2015). The Global Burden of Disease: 2004 Update. Geneva: WHO Press.

Misha, F., \& Sulaiman, M. (2016). Bangladesh Priorities: Poverty, Sulaiman and Misha Copenhagen Consensus Center. Copenhagen Consensus.

http://www.copenhagenconsensus.com

Mohit, M. A., Maruf, M. M., Ahmed, H., \& Alam, M. T. (2011). Depression and Physical Illnesses: An Update. Bangladesh Medical Journal, 40, 53-58. https://doi.org/10.3329/bmj.v40i1.9966

More, H. (2020). https://hefactfactor.com/facts/law/legal concepts/criminology/what-is-crime-and-cri $\underline{\text { minology/7004 }}$

Paranjape, N. V. (2007). Criminology and Penology (12th ed.). Allahabad: Central Law Publication.

Patten, S. B. (2000). Incidence of Major Depression in Canada. CMAJ, 163, 714-715. 
Poverty in Bangladesh, P.B. (2020). Rural Poverty in Bangladesh. Rural Recovery Portal.

Rana, M. S., \& Nesa, M. (2018). Illegal Fire Arms in Bangladesh: Key Actors. SARJANA, $33,30-42$.

Sadock, B. J., \& Sadock, V. A. (2003). Synopsis of Psychiatry: Behavioral Science/Clinical Psychiatry (9th ed.). Philadelphia, PA: Lippincott Williams.

Saunders, C. J. (2001). Rape and Ravishment in the Literature of Medieval England (p. 20). Cambridge: D. S. Brewer.

SAWAB (2020). Poverty Alleviation Program-SAWAB-A Non Government Organization of Bangladesh.

Shi, Y. L. (2019). http://www.xinhuanet.com/english/2019-02/27/c 137855105.htm

Sutherland, E. H. (1934). Principles of Criminology (2nd ed., p. 4). Philadelphia, PA: Lippincott Publishers.

Terrorism in Bangladesh (2020).

https://www.satp.org/satporgtp/countries/bangladesh/database/Fatalities,Islamist\%20T errorism\%202010.htm

The World Fact Book (2018). Bangladesh: People and Society. Central Intelligence Agency.

World Population Prospects, WPP (2019). Population Division of the Department of Economic and Social Affairs of the United Nations Secretariat. 